\title{
REMOVING RETICENCE LEADING TO TRANSFORMATION IN NEGATIVE PERCEPTION THROUGH EXPERIMENTAL DESIGN
}

\author{
Mumtaz Muhammad Khan*, Asma Tahir $†$ \& \\ Muhammad Tahir Khan
}

\begin{abstract}
The high demand in salesforce could not generate business students' shift towards this profession despite prevailing global unemployment. Removing students' reticence about sales careers can help motivate them to espouse sales careers, meet this demand-driven profession's challenges, and help eradicate unemployment. This study examines the impact of roleplaying and guest speaker expert presentation through experimental research design by using a randomized trial method in changing students' negative perceptions about a sales career with the intent to pursue it. This study used the t-test analysis that depicted the students' perception regarding sales career and the regression analysis that elucidate a direct impact of student' perception on their intent to pursue a sales career. The results show that role-play and presentation by guest speaker interventions significantly impact the changing students' negative perceptions about sales careers. The regression analysis shows that all sales perception subscales directly impact students' intent to pursue a sales career. The study is useful for policymakers, sales experts, researchers, and practitioners.
\end{abstract}

Keywords: Sales career; guest speaker expert; role-play; experimental research design;

\footnotetext{
Associate Professor, Department of Management Sciences, Imperial College of Business Studies, Lahore.

+ Department of Management Sciences, National College of Business Administration \& Economics, Lahore, Pakistan.

₹ Assistant Professor, Department of Economics and Business Administration, Division of Arts and Social Sciences, University of Education. Lahore.
} 


\section{Introduction}

The sales function is considered as the lifeblood of marketing and a professionally trained sales force. The world is facing a severe shortfall of professional salespeople today and in the future (Tytler, Bridgstock, White, Mather, McCandless, \& Grant-Iramu, 2019). Despite the increasing demand for professionally trained salespeople, most business students are not interested in pursuing their careers in this field due to a lack of interest and negative perception of the sales profession. The students' negative perception regarding sales career is associated with their thinking wherein they consider it low prestigious, unethical, and unimpressive.

The role of different selling processes, sales management structures, and the strategic use of personal selling within the broader promotion mix is critical in a marketing plan (Katsikea, Theodosiou, \& Makri, 2019). If students' negative perceptions of a selling career prevent full exploration of the essential role sales can play in the broader marketing mix, educators have done damage to students and the business community by not addressing this issue (Boone, Kurtz, Khan, \& Canzer, 2019). Following this line of research demands investigating factors that can change students' negative perceptions about sales careers.

Marketing educators intend to train students professionally and prepare them to serve in the market (Key, Czaplewski, \& Ferguson, 2019). By investigating the role of role-playing and presentation of sales experts, this study may enhance students' intention to carry on a sales career. The study highlights the order in which these interventions impact students' perception. It guides marketing educators in applying non-conventional practices in the right order. The research is significant for strategic course development by offering new ways to introduce in business classes. We are investigating this problem in the context of a developing country, Pakistan.

\section{Research Questions}

This study focuses on evaluating the impact of role-playing and presentation of sales expert as educational practices in generating positive sales career perception, aimed at finding answers to the following questions;

1. Do role-play and guest speaker expert presentations reduce the student's negative perception about a sales career?

2. Will the students' positive perception about sales career help them pursue their career in the sales profession?

3. Which of the two interventions has a higher impact on reducing students' negative perceptions about a sales career? 


\section{Objectives of the Study}

To answer the above questions, the objectives of the study are;

1. To assess the impact of non-conventional and innovative teaching methods in changing students' perceptions about sales careers.

2. To examine the effect of students' perceptions about sales on their intention to pursue sales as a career.

\section{The Significance of the Study}

Barendsen \& Henze (2019) illustrate the advantages of modeled learning as it provides a low-risk environment for business graduates compared to actual sale situations. The availability of this information develops a sense of sales efficacy among students. Sales education has drastically developed in response to the recent increase in demand for sales skills. Selling has become more sophisticated and solutions-oriented. Still, sales jobs go unfilled (Fogel et al., 2012). In response to the call for modernizing educational practices (DeBoer, 2019), this study proposes two interventions: role play and sales expert presentation tested on first semester students studying the principle of marketing class in a private sector university in Pakistan. Roleplaying activity by sales team and students interact and participate in developing an understanding of sales ethics, salespeople, sales career, and sales knowledge to improve their perceptions and understanding. A sales expert having ten years' proven experience in the sales and marketing field from a well-reputed organization is designed to deliver a presentation with a learning goal to enhance general perceptions regarding sales ethics, salespeople, sales career, and sales knowledge.

\section{Literature and Hypothesis Development}

\section{Role Play}

Role-playing refers to a technique to study interpersonal behavior in which a person is assigned to do a task and assume that the set of conditions are real (Beauvois, \& Joule, 2019). Barton \& Stacks (2019) elaborate on role-playing as the most effective teaching method in sales literature. The usefulness of role-playing can be multiplied when students repeat their activities in the real-world (Damayanti, Parta, \& Chandra, 2019). The method of role-playing helps get students' attention and concentration in the class (Adams, 2019). Roleplaying improves the students' interpersonal communication skills by providing practical information about sales activities (Kao, 2019). Adding in sales role-playing activities can significantly add up students' learning about sales functions (Flaherty et al., 2019). In class, role-playing exercises give a chance to students to selfidentify according to the situation. 
It is a consensus among marketing educators that taking marketing courses motivates students to take on a sales career; further research is required to investigate the best curricula to achieve this goal (Nordstrom, 2019). Dugan et al. (2019) investigated mock interviews' role in shaping students' positive views about sales careers. The use of salesforce socialization in formulating students' positive expectations can be a unique method in gaining students' favorable responses to the sales profession (Mulki, \& Lassk, 2019). Even though these techniques helped remove business graduates' negative views, including such techniques is somewhat tricky.

Engaging students in sales role-playing allows them to apply their salesrelated skills and knowledge to a situation similar to the real-world environment (Boone et al., 2019). Haywood, \& Mishra, (2019). explain that in introductory marketing classes, students grasp sales vocabulary and gain interpersonal skills while they refine these skills by participating in experiential activities, i.e., role-playing. Sales executives prefer to hire those who have role-playing experience in classrooms as better performers (Bush, 2019). Following this line of research, this study hypothesizes that role-play activity by sales team and students when they interact and participate in developing an understanding of sales ethics, salespeople, sales career, and sales knowledge to improve their perceptions and understanding regarding them may positively impact their understanding of the intent to pursue sales career:

H1: Role Playing can significantly improve students' perception regarding sale career

\section{Guest Speaker-Expert Presentation}

Guest speaker appearance is one of the widely used non-conventional methods to motivate students. Students' discretion to follow a sales career can be enhanced if they have enormous sales experienced (Ford, 2019). Kaushik \& Schulte (2019) investigate that business graduates who have never interacted first-hand with any salesperson may take the sales profession in a negative sense. The sales peers can mitigate the negative perception among students by arousing innovation among students.

Itani et al. (2019) suggest that an expert panel on sales significantly impact sales ethics and sales career. Mulki et al. (2019) also reveal a considerable impact of the sales expert group on students' perception. Practical knowledge through a credible resource person can be a fruitful tool to develop their critical thinking. Cameron \& Green (2019) argue that a person with vast sales experience can reduce students' reticence the most. Following this direction, this study hypothesizes that a salesperson expert having handsome proven experience in a renowned organization may interact and deliver a presentation with a learning goal to enhance general and specific perceptions regarding sales ethics, salespeople, sales career, and 
sales knowledge, to create a positive impact on students' perception about their intent to pursue a sales career.

H2: Guest speakers' presentation (sales expert) significantly impacts students' perception of a sales career.

\section{Sales Profession Subscale}

Based on the aforementioned sales dimensions: sales ethics, salespeople, sales career, and sales knowledge, Gringarten et al. (2019) aggregated various items from the literature to develop a parsimonious scale for measuring student intends to pursue a sales career after graduation. The sales profession subscale addresses the personal fulfillment and value of a sales job to the individual, while the salesperson subscale asks about the perception of and respect given to salespeople by others. Sales ethics addresses the ethical practices and responsibilities of salespeople. The salespeople subscale addresses the image of the salespeople. Sales career addresses the sales career's image concerning other careers available to the people to pursue this profession. Finally, sales knowledge refers to the individual's familiarity with sales practices and the ability to perform these processes.

In the current research, Students' perception about the sale, career acts as a mediating variable. The researcher is interested in knowing the impact of non-conventional teaching practices on students' sales career perception, which influences their intention to follow a sales career. Based on the above arguments, we hypothesize that;

H3: Reducing significantly sales perception will enhance the likelihood of a student's intent to pursue a sales career.

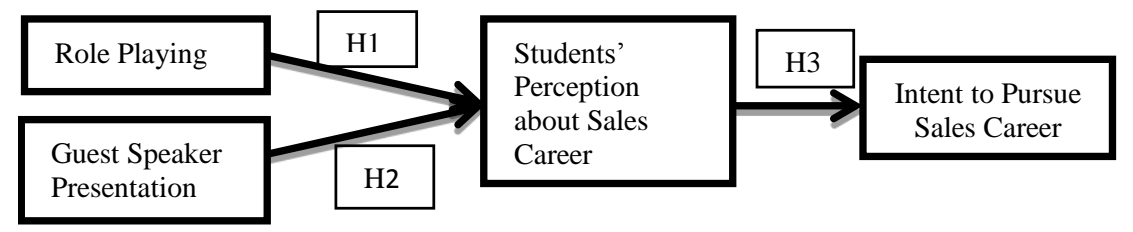

\section{Figure-1: Change in Students' Perception}

\section{Research Methodology}

\section{Research Strategy - Experiment}

Research design is an overall blueprint of how the research questions, broader and specific objectives of the study are to be addressed (Meeks et al., 2019). Following the research design onion, the present study's research design is experimental design, which helps identify the causal link between role play and sales expert presentation and the intention to pursue a sales 
career (Janke, \& Dickhäuser, 2019). To test our study hypothesis, an experiment is conducted with Bachelor of Business Administration (BBA) students of a private university for both the interventions. Collecting longitudinal data can measure the change in students' intention to pursue a sales career due to role play and presentation by sales experts. Keeping in mind the nature of the research question, the data was collected at two points of time, $\mathrm{T} 1$ and $\mathrm{T} 2$ fromthe individual as a unit of analysis.

\section{Pilot Testing}

A pilot study is conducted before administrating the questionnaire to the actual sample. The questionnaires are distributed in BBA classes of two private universities. YousafZai, \& Fareed (2019) suggested that students for the current study are chosen from their course's early semesters. Students are instructed to demonstrate their original responses without any manipulation. Further, they are assured that their responses are kept anonymous and will not impact their class grades. All students show some confusion while understanding the questionnaire items. Therefore, we have added some explanations for each subscale explaining the context of the study. Besides, oral instructions are also incorporated while collecting actual data.

\section{Population and Sampling}

The current study population is university students, further narrowed down to first-year marketing class business students as they are most likely to adopt sales as a career. These students have not established firm beliefs about sales careers; therefore, they can be guided.

To draw a sample from this target population, we adopted a convenience sampling technique. Convenience sampling is used if little variation exists in a given population (Crane, Matten, Glozer, \& Spence, 2019; Khan, Rehman \& Hashmi, 2020)).In Pakistan, all students enter degree business class after completing twelve years of education. Further several centralized policies imposed by the Higher Education Commission on business schools make them very much similar. We conclude that little variation exists in the targeted population, business students at the bachelor level. The data is collected from the Bachelor of Business Administration (BBA) classes taught by a private university teacher.

\section{Randomized Controlled Trials}

The students are distributed between controlled and experiment groups by using randomized controlled trials to minimize researcher biases. Two BBA classes are selected to run this experiment. For each intervention, fifteen students are randomly assigned to participate in a particular intervention (e.g., role-playing and presentation by sales expert) for an experimental group, while no intervention is made with the controlled group. 


\section{Analysis and Results}

\section{Applying Planned Interventions}

Two interventions Role-play and guest speaker experts are applied in phases with different stages. In phase 1, the activity of role-playing is applied. Before applying role-playing activity, preliminary data is collected from both controlled and experiment groups consisting of fifteen randomly assigned students. In the next stage, the role-playing activity is performed with students from the experiment group. A business simulation video is shown to students wherein an entrepreneur tries to sell his/her business idea in front of a group of investors. The students are then asked to perform the same activity and try to sell their business ideas. On the other hand, no activity is performed by the control group. In the final stage, data is collected from both the experiment and control groups to compare and identify any change in students' perception and intention to pursue a sales career.

In the second phase, the activity of the guest speaker presentation (sales expert) is performed. Again the students are divided into two groups by using the technique of randomization. The students in the experiment group attended the presentations. The purpose of presentations is to teach students about real practical sales practices. The presenter shared his personal experiences regarding personal selling, sales ethics, and career development in this area. However, no such presentation is given to students of the control group. The data is collected from both groups before and after the application of this intervention. The data for each of the two interventions is collected from two groups comprising 15 students in each group with a male, female distribution according to the relative strength of class at $\mathrm{T} 1$ and $\mathrm{T} 2$, as shown in Table 1.

Table 1: Detail of Intervention in Experiment and Controlled Groups

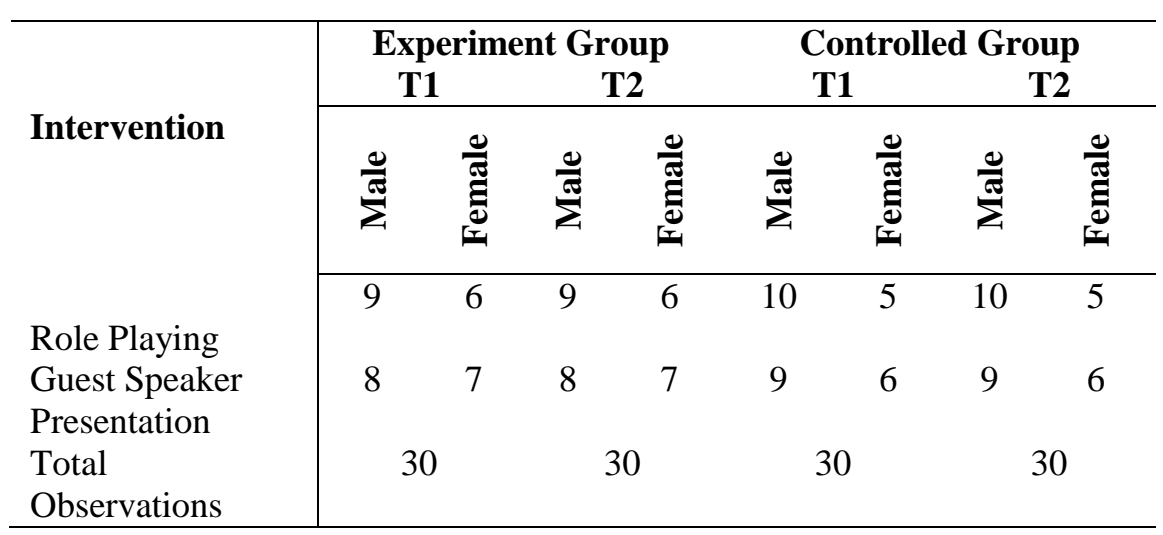




\section{Analytical Strategies}

To test our study hypotheses, data is analyzed using SPSS and investigating the difference in pre-test post-test observation for both experiments and controlled groups. The t-test is used. Students' perception is analyzed for both studied interventions. A comparative analysis is also conducted to examine more effective non-conventional teaching practices. Finally, regression analysis is conducted to examine the impact of sales perception on students' intent to pursue a sales career.

\section{Data Screening: Missing Values, Data Normality, and Outliers}

In social and management sciences research, different problems and issues faced by research in the data or model, such as missing values and outliers in the data while omitted variables biases and issues of heterogeneity and endogeneity, which results in an inappropriate finding (Khan, Saif, Jabri and Rahman, 2020; Khan, Rehman, and Hashmi, 2020). In social and behavioral sciences, the researchers often face missing values (Fallon, 2019). Missing few values do not impact statistical results. However, missing values in large quantities may generate serious concerns in final data analysis and lead to unreliable results. Some of the statistical tests cannot be performed in the presence of missing values. Following these guidelines, we found that out of 120 cases, 7 cases were very critical because of $60 \%$ missing data, which are excluded from the final analysis. However, the missing values in nominal cases are filled in by the "replace with mean" method suggested by Mavrogiorgou et al. (2019). The analyses are performed in 113 cases.

The normality of the data can be calculated either through a statistical or graphical way (Petrie, A., \& Sabin, C. 2019). Although both techniques are used for normality tests, a large set of graphical data analyses becomes unwieldy and impractical. As the current study's data file has 113 cases, we chose a statistical technique to test normality. In the first step, KolmogorovSmirnov and Shapiro-Wilk tests of normality were tested as reported in Table 2. This test showed significant values of all variables and indicated that data is not normally distributed.

Table 2: Test of Normality

\begin{tabular}{lllllll}
\hline \multirow{2}{*}{ Sub Scales } & \multicolumn{2}{l}{ Kolmogorov-Smirnov $^{\text {a }}$} & \multicolumn{2}{c}{ Shapiro-Wilk } & \\
& Statistic & df & Sig. & Statistic & df & Sig. \\
\hline SP Mean & .146 & 113 & .000 & .887 & 113 & .000 \\
SK Mean & .119 & 113 & .000 & .926 & 113 & .000 \\
SP Mean & .092 & 113 & .000 & .964 & 113 & .000 \\
SE Mean & .093 & 113 & .000 & .976 & 113 & .000 \\
ITP Mean & .129 & 113 & .000 & .922 & 113 & .000 \\
\hline
\end{tabular}

$\mathrm{SP}=$ Sales Profession, $\mathrm{SK}=$ Sales Knowledge, $\mathrm{SP}=$ Sales People, $\mathrm{SE}=$ Sales Ethics, ITP= Intent to Pursue 
Another normality test is applied to verify the normal distribution of data, and the values of skewness and kurtosis are calculated. Values of both skewness and kurtosis for all items fall between +1.5 to -1.5 , as reported in Table 3 the recommended values. These values established a quasi-normal distribution of our data set.

Table 3: Values of Skewness and Kurtosis

\begin{tabular}{llllll}
\hline Description & SP Mean & SK Mean & $\begin{array}{l}\text { SP } \\
\text { Mean }\end{array}$ & $\begin{array}{l}\text { SE } \\
\text { Mean }\end{array}$ & $\begin{array}{l}\text { ITP } \\
\text { Mean }\end{array}$ \\
\hline Skewness & -1.399 & -1.043 & -.652 & -.323 & -1.039 \\
Std. Error of Skewness & .113 & .113 & .113 & .113 & .113 \\
Kurtosis & 1.131 & 1.225 & 1.429 & -.156 & 1.134 \\
Std. Error of Kurtosis & .225 & .225 & .225 & .225 & .225 \\
\hline
\end{tabular}

Finally, the outliers in data were identified by using the Mahalanobis distance measuring method. (Sunderland et al., 2019) suggested that cases with Mahalanobis alpha level of .001 would be considered as outliers. By following (Souza, Aquino, \& Gomes's, 2019) guidelines, we have calculated the critical chi-square value using four independent variables and found that no case has less than .001 value. Therefore, no outliers are found.

\section{Scale Reliabilities, Correlation Matrix and Impact on Intent to Pursue Sales Career}

Scale reliabilities, the correlation among sales perception subscales, and intent to pursue sales career support this study claims. The Cronbach alpha of all variables except the sales profession (0.69) is more significant than 0.70 , the recommended threshold value for scale reliability (Khan, Jabri, and Saif, 2019). Next, the Table shows the correlation among variables. The correlation among any two variables did not exceed.90, therefore, we did not find any multicollinearity issue among sales perception subscales. Further, the correlation matrix shows that all independent variables about sales perception are significantly correlated with the dependent variable, the intent to pursue. It provides initial support to our hypotheses. It is also essential to find out whether this favorable perception about a sales career leads to adopting a sales career or not? To test this hypothesis, the researcher regress sales perception subscales on students' intention to pursue a sales career. Among all four sales perception subscales, sales knowledge has the most substantial impact $(\boldsymbol{\beta}=\mathbf{. 3 9 8})$ on intent to pursue a sales career. On the other hand, sales ethics is lowest in students' intent to pursue a sales career $(\boldsymbol{\beta}=.126)($ Table 4). 
Table 4: Sub-scale Reliability, Correlation, and Intent to Pursue Sales Career

\begin{tabular}{lllllllll}
\hline \multicolumn{1}{c}{ Variables } & Alpha & $\begin{array}{c}\text { Standa } \\
\text { rd } \boldsymbol{\beta}\end{array}$ & \multicolumn{1}{c}{$\mathbf{1}$} & \multicolumn{1}{c}{$\mathbf{2}$} & $\mathbf{3}$ & $\mathbf{4}$ & $\mathbf{5}$ \\
\hline 1. Sales Profession & 0.69 & $0.250^{* *}$ & 1 & & & & & \\
2. Sales knowledge & 0.72 & $0.398^{* *}$ & 0.190 & 1 & & & \\
3. Sales People & 0.73 & $0.215 * *$ & 0.250 & 0.266 & 1 & & \\
4. Sales Ethics & 0.81 & $0.126^{*}$ & 0.080 & 0.452 & 0.103 & 1 & \\
5. Intent to Pursue & 0.75 & $0.514 * *$ & $0.407 *$ & $0.610 * *$ & $0.437 *$ & $0.773 * *$ & 1 \\
\hline * $\mathrm{p}<0.05, * * \mathrm{p}<0.01$ & & & & & &
\end{tabular}

\section{Hypothesis Testing}

The impact of two teaching interventions, role-playing and guest speaker presentations, on students' perceptions about sales, are highlighted through the difference in pre-test and post-test values. The results of the ttest show that the impact of sales competition on all four dimensions of sales perception remains significant, as shown in Table 5. Therefore, it supports our hypothesis H1. In analyzing the sales role-playing effect on students' sales perception, the results describe that role-playing significantly impacts all sales perception dimensions except sales ethics. It supports our hypothesis H2. Finally, the application of intervention, guest speaker presentation shows partial support for our hypothesis H3. Only two sales perception dimensions show significant change due to the application of a guest speaker presentation. However, the perception about the sales profession and sales ethics dimension shows insignificant change due to guest speaker presentation. No intervention is applied to controlled groups. The $t$-test analysis shows the insignificant change in the pre-test and posttest means of each intervention's sales perception dimension.

Table 5: Role-Playing Impact on Sales Perception Subscales (Experimental \& Controlled Group)

\begin{tabular}{|c|c|c|c|c|c|c|c|c|}
\hline \multirow[t]{3}{*}{ Dimension } & \multicolumn{4}{|c|}{ Role Play } & \multicolumn{4}{|c|}{ Presentation Guess Speaker } \\
\hline & \multicolumn{2}{|c|}{$\begin{array}{l}\text { Experimental } \\
\text { Group }\end{array}$} & \multicolumn{2}{|c|}{$\begin{array}{l}\text { Controlled } \\
\text { Group }\end{array}$} & \multicolumn{2}{|c|}{$\begin{array}{c}\text { Experimental } \\
\text { Group }\end{array}$} & \multicolumn{2}{|c|}{$\begin{array}{l}\text { Controlled } \\
\text { Group }\end{array}$} \\
\hline & $\begin{array}{c}\text { T1 } \\
\text { Mean } \\
\text { \& SD }\end{array}$ & $\begin{array}{c}\text { T2 } \\
\text { Mean } \\
\text { \& SD }\end{array}$ & $\begin{array}{c}\text { T1 } \\
\text { Mean } \\
\& \text { SD }\end{array}$ & $\begin{array}{c}\text { T2 } \\
\text { Mean } \\
\& \text { SD }\end{array}$ & $\begin{array}{c}\text { T1 } \\
\text { Mean } \\
\text { \& SD }\end{array}$ & $\begin{array}{c}\text { T2 } \\
\text { Mean } \\
\text { \& SD }\end{array}$ & $\begin{array}{c}\text { T1 } \\
\text { Mean \& } \\
\text { SD }\end{array}$ & $\begin{array}{c}\text { T2 } \\
\text { Mean } \\
\text { \& SD }\end{array}$ \\
\hline Sales & 2.60 & 4.20 & 3.05 & 2.99 & 3.20 & 3.26 & $3.11(.57)$ & 3.13 \\
\hline Profession & $(.48)$ & $(.26)^{* *}$ & $(.32)$ & (.36) & (.35) & (.29) & & (.42) \\
\hline & 2.38 & 4.25 & 2.63 & 2.65 & 3.00 & 3.66 & $2.67(.47)$ & 2.66 \\
\hline Knowledge & $(.40)$ & $(.33)^{* *}$ & $(.41)$ & (.39) & (.45) & $(.52) * *$ & & $(.58)$ \\
\hline Sales & 3.16 & 4.26 & 3.19 & 3.15 & 2.90 & 3.04 & $2.38(.61)$ & 2.45 \\
\hline People & $(.58)$ & $(.41)^{* *}$ & $(.43$ & $(.52)$ & (.62) & $(.56) * *$ & & (.56) \\
\hline Sale & 2.88 & 2.52 & 2.90 & 2.78 & 3.84 & 3.78 & $3.71(.37)$ & 3.77 \\
\hline Ethics & $(.58)$ & $(.27)$ & (.47) & (.40) & (.40) & $(.32)$ & & (.38) \\
\hline
\end{tabular}




\section{Findings of the Study}

The t-test analysis shows that students' perception regarding sales careers is changed due to role-playing and guest speakers' presentations. The latter has a weaker relation between the two interventions. Finally, the regression analysis confirms that students' perception directly impacts their intent to pursue a sales career.

Applying the useful teaching model to sales topics, marketing educators can infer that effective teaching can help students think critically about the sales roles in marketing. Modern sales education helps students understand their sales-related skills and capabilities (Yeoh, 2019). It encourages students to learn more practical aspects of the sales profession. With this aim in mind, the researcher established and tested two interventions.

Students' perception about sales career is measured and analyzed by focusing on the following dimensions: 1) sales profession (the perceived value and level of fulfillment from sales career), 2) sales ethics (ethical responsibilities of salesforce), 3) salespeople (the societal view about salespeople) and 4) sales knowledge (theoretical as well as practical knowledge about selling activities). Students' perception of all four dimensions changes significantly after applying this intervention.

The study findings also support researcher's hypothesis that role-playing play a significant role in changing students' negative perception. Using roleplaying as a perception-changing tool, the researcher found that students show a significant change in three dimensions of sales perception (sales profession, sales knowledge, and salespeople). However, this activity brings no change in students' perceptions of sales ethics. It might be because, during sales role-playing, students' focus remained on winning their project, and they were well prepared in terms of sales knowledge and sales profession. Another possible reason might be their exposure and interaction with investors (acting), not with customers. Therefore they could not face any ethical/unethical dilemma.

The teaching intervention of guest speakers' presentations brings a partial change in students' perception of sales. By applying this intervention, students perceive salespeople and sales knowledge as positive but not about the sales profession and sales ethics. It might be because presentations given by guest speakers have more resemblance to traditional classroom lectures. The presentation skills of sales experts can be a potential factor in bringing in significant changes in students' perceptions.

Finally, the researcher aims at examining whether the change in students' perceptions can change their desire to adopt a sales career? The regression analysis shows the significant impact of students' perception of their intention to pursue a sales career. It shows that the primary reason for avoiding a sales career is the misconception about sales knowledge, sales 
profession, salespeople, and sales ethics. Once this perception is eliminated, students are willing to adopt this profession enthusiastically.

\section{Implications and Future Directions}

In sum, the results of current research afford two significant repercussions for marketing educators and scholars in determining the antecedents of changing students' negative perception: To admit the importance of socialization of future salesforce as a facilitative tool in guiding sales education pedagogy and to better prepare business graduates for sales career-focused on practical based sales job behavior.

This study has several implications for different stakeholders. The study suggests new innovative teaching methods to equip students with real-time sales job skills and marketing educators' behaviors. The study also guides the policymakers in defining the sales curriculum by incorporating modern ways of teaching. Our research highlighted the importance of learning by doing techniques instead of traditionally class-based lecture techniques. Finally, it helps organizations to hire skillful salespeople having experience in activities similar to real sales practices.

First, the interventions are applied to only one university. Further research can expand the generalizability of the study by applying interventions in more than one university. The comparison of students' perceptions in different universities can enhance the scope of the topic.

Only two role-play and guest speaker presentations are used in the current study to change students' negative sales perceptions. Additional interventions such as sales competition, alumni guest speakers can be utilized to remove students' reticence and increase their intent to pursue a sales career. The use of academic-industry linkages can also help students in ameliorating their conceptions about sales. These linkages expose students to real-time sales knowledge and practices and remove many of their fallacies about sales.

The actual experiment study helps us establish a causal relationship between educational interventions and students' sales perception. The insignificant changes in students' perception in the controlled group highlight that changes in perception in the experiment group are due to studied interventions. This study advanced our knowledge of sales education by conducting an experimental study in a developing country, i.e., Pakistan.

\section{References}

Adams, J.L. (2019). Conceptual blockbusting: A guide to better ideas. Hachette UK. 
Barendsen, E., \& Henze, I. (2019). Relating teacher PCK and teacher practice using classroom observation. Research in Science Education, 49(5), 1141-1175.

Barton, M., \& Stacks, S. (2019). Dungeons and Desktops: The History of Computer Role-Playing Games $2 e$. AK Peters/CRC Press.

Beauvois, J.L., \& Joule, R.V. (2019). A radical point of view on dissonance theory.

Boone, L.E., Kurtz, D.L., Khan, M.H., \& Canzer, B. (2019). Contemporary business. John Wiley \& Sons.

Bush, S. (2019). Putting on the red boots: role-play as 'coping work'and 'creative work'in the theatrical representation of prostitution. Studies in Theatre and Performance, 39(1), 54-69.

Cameron, E., \& Green, M. (2019). Making sense of change management: A complete guide to the models, tools and techniques of organizational change. Kogan Page Publishers.

Cervellon, M.C., Poujol, J.F., \& Tanner Jr, J.F. (2019). Judging by the wristwatch: Salespersons' responses to status signals and stereotypes of luxury clients. Journal of Retailing and Consumer Services, 51, 191201.

Cho, M.H., \& Castañeda, D.A. (2019). Motivational and affective engagement in learning Spanish with a mobile application. System, 81, 90-99.

Cohen, D., Vlaev, I., McMahon, L., Harvey, S., Mitchell, A., Borovoi, L., \& Darzi, A. (2019). The Crucible simulation: Behavioral simulation improves clinical leadership skills and understanding of complex health policy change. Health care management review, 44(3), 246-255.

Crane, A., Matten, D., Glozer, S., \& Spence, L. (2019). Business ethics: Managing corporate citizenship and sustainability in the age of globalization. Oxford University Press.

Damayanti, N.W., Parta, I.N., \& Chandra, T.D. (2019, June). Student Algebraic Reasoning to Solve Quadratic Equation Problem. In Journal of Physics: Conference Series (Vol. 1227, No. 1, p. 012025). IOP Publishing.

DeBoer, G. (2019). A history of ideas in science education. Teachers college press.

Dugan, R., Hochstein, B., Rouziou, M., \& Britton, B. (2019). Gritting their teeth to close the sale: the positive effect of salesperson grit on job satisfaction and performance. Journal of Personal Selling \& Sales Management, 39(1), 81-101.

Fallon, M. (2019). Writing up quantitative research in the social and behavioral sciences. Brill Sense.

Fogel, S., Hoffmeister, D., Rocco, R., \& Strunk, D. (2012).Teaching sales: Great sales professionals are scarce and getting scarcer. Why aren't 
universities working harder to create more? Harvard Business Review, 1-7.

Ford, H. (2019). Today and Tomorrow: Commemorative Edition of Ford's 1926 Classic. Routledge.

Franklin, J.A. (2019). United States Foreign Policies on Iran and Iraq, and the Negative Impact on the Kurdish Nationalist Movement: From the Nixon Era through the Reagan Years (Doctoral dissertation, Wright State University).

Gringarten, H., \& Fernández-Calienes, R. (Eds.). (2019). Ethical Branding and Marketing: Cases and Lessons. Routledge.

Haider, M., Aamir, M., \& Tahir, M. (2019). International Financial Reporting Standards, Accounting Conservatism, and Firm Performance: Evidence from UAE. 4(3), 284-295.

Haywood, M.E., \& Mishra, A. (2019). Building a culture of business analytics: a marketing analytics exercise. International Journal of Educational Management, 33(1), 86-97.

Itani, O.S., Jaramillo, F., \& Chonko, L. (2019). Achieving top performance while building collegiality in sales: It all starts with ethics. Journal of Business Ethics, 156(2), 417-438.

Jacobson, N.S., \& Margolin, G. (2019). Marital Therapy Strategies Based On Social Learning \& Behavior Exchange Principles. Routledge.

Janke, S., \& Dickhäuser, O. (2019). A neglected tenet of achievement goal theory: Associations between life aspirations and achievement goal orientations. Personality and Individual Differences, 142, 90-99.

Jobber, D., Lancaster, G., \& Le Meunier-FitzHugh, K. (2019). Selling and sales management. Pearson UK.

Kang, D., Ryu, S., \& Lee, S.H. (2019). I need to be your only friend: the effect of salesperson network centrality on opportunistic behavior. Journal of Personal Selling \& Sales Management, 39(2), 159-171.

Kao, C.C. (2019). Development of Team Cohesion and Sustained Collaboration Skills with the Sport Education Model. Sustainability, 11(8), 2348.

Katsikea, E., Theodosiou, M., \& Makri, K. (2019). The interplay between market intelligence activities and sales strategy as drivers of performance in foreign markets. European Journal of Marketing.

Kaushik, C., \& Schulte, F. (2019). Study on Sales Practitioners in B2B Companies-Ideal Conception and Practical Challenges of the Job Profile.

Key, T.M., Czaplewski, A.J., \& Ferguson, J.M. (2019). Preparing workplace-ready students with digital marketing skills. Marketing Education Review, 1-5.

Khan, M.T., Al-Jabri, Q.M., \& Saif, N. (2019). Dynamic relationship between corporate board structure and firm performance: Evidence from 
Malaysia. International Journal of Finance \& Economics. 1-18. https://doi.org/10.1002/ijfe.1808

Khan, M.T., Rehman H., \& Hashmi, A. (2020). Corporate Governance Practices and Its Effect on Corporate Financial Performance: A Pragmatic Evidence from Malaysia. Pakistan Journal of Humanities and Social Science Research, 3(1), 177-194.

Khan, M.T., Saif, N., Al-Jabri, Q., Rahman, H. (2020). Impact of accrual reversals on corporate performance: evidence from emerging economy. International Journal of Managerial and Financial Accounting, 12(3/4), 328-341. https://www.inderscience.com/info/inarticle.php?artid=112362

Knowles, R.T. (2019). Ideological composition of the classroom: testing the effects of polarization on perceptions of open classroom climate among students in five countries. Educational Psychology, 1-19.

Lancaster, S.J., \& Topper, A. (2019). Designing and Implementing a Student-Centered Online Graduate Program: A Case Study in a College of Education. In Student-Centered Virtual Learning Environments in Higher Education (pp. 157-184). IGI Global.

Leonidou, C.N., \& Hultman, M. (2019). Global marketing in business-tobusiness contexts: Challenges, developments, and opportunities.

Mavrogiorgou, A., Kiourtis, A., Perakis, K., Miltiadou, D., Pitsios, S., \& Kyriazis, D. (2019). Analyzing data and data sources towards a unified approach for ensuring end-to-end data and data sources quality in healthcare 4.0. Computer methods and programs in biomedicine, 181, 104967.

Meeks, S.L., Herzog, R.W., \& Members of Working Group 3, the NHLBI State of the Science Workshop on factor VIII inhibitors: Generating a national blueprint for future research. (2019). The national blueprint for future basic and translational research to understand factor VIII immunogenicity: NHLBI State of the Science Workshop on factor VIII inhibitors. Haemophilia, 25(4), 595-602.

Mulki, J., \& Lassk, F.G. (2019). Joint impact of ethical climate and external work locus of control on job meaningfulness. Journal of Business Research, 99, 46-56.

Nordstrom, A. (2019). Social Impact Through Business: A Comparative Analysis of Undergraduate Course Offerings and Perceptions of University Support.

Petrie, A., \& Sabin, C. (2019). Medical statistics at a glance. John Wiley \& Sons.

Price, J.N., Good, M.K., Schultz, N.L., Guja, L.K., \& Morgan, J.W. (2019). Multivariate drivers of diversity in temperate Australian native grasslands. Australian Journal of Botany, 67(5), 367-380.

Saif, N., Khan, M.T., Shaheen, I., \& Bangash, S.A. (2020). Neglected Field of Research Related to Job Insecurity and Outcomes in Pakistan. City University Research Journal, 10(2), 358-378. 
Saif, N., Khan, M.T., Ali, S., \& Wadood, F. (2019). Laohavichien model of Leadership and Quality for Pakistan. What it is and why it's important for SME's. IBT Journal of Business Studies (JBS), 15(2), 43 - 61.

Selimbegović, L., Karabegović, M., Blažev, M., \& Burušić, J. (2019). The independent contributions of gender stereotypes and gender identification in predicting primary school pupils' expectancies of success in STEM fields. Psychology in the Schools.

Shah, S.A.M. (2019). Consumer Ethical Decision Making in Pakistan (Doctoral dissertation, COMSATS Institute of Information Technology, Islamabad).

Souza, T.I., Aquino, A.L., \& Gomes, D.G. (2019). A method to detect data outliers from smart urban spaces via tensor analysis. Future Generation Computer Systems, 92, 290-301.

Stelzer, E.M., Knowles, L.M., Wilson, D.M.T., \& O'Connor, M.F. (2019). Recruitment and retention in clinical and experimental bereavement research: Lessons learned from creating a research registry. Death studies, 1-7.

Sunderland, K.M., Beaton, D., Fraser, J., Kwan, D., McLaughlin, P.M., Montero-Odasso, M., ... \& Strother, S.C. (2019). The utility of multivariate outlier detection techniques for data quality evaluation in large studies: an application within the ONDRI project. BMC medical research methodology, 19(1), 102.

Tytler, R., Bridgstock, R.S., White, P., Mather, D., McCandless, T., \& Grant-Iramu, M. (2019). 100 Jobs of the Future.

U.S. Bureau of Labor Statistics (2014). Occupational outlook hand book. Retrieved from http://www.bls.gov/ooh/.(ckh the site)

Vandenberghe, C., Panaccio, A., Bentein, K., Mignonac, K., Roussel, P., \& Ayed, A.K.B. (2019). Time-based differences in the effects of positive and negative affectivity on perceived supervisor support and organizational commitment among newcomers. Journal of Organizational Behavior, 40(3), 264-281.

Yeoh, P.L. (2019). A critical assessment of skills and knowledge for entrylevel marketing jobs. A Delphi study. Marketing Education Review, 124.

YousafZai, R.A., \& Fareed, M. (2019). ESP Teaching Practices in Management Science at Post-Graduate Level in Pakistan: Perception of ESP Teachers and ESP Learners. Journal of Management Sciences, 6(1), 1-14. 